\title{
Perancangan dan Implementasi Tracking Solar Cell System dengan Menggunakan Overload Protection
}

\author{
Agung Wijaya $^{1}$, Bengawan Alfaresi ${ }^{2 *}$, Feby Ardianto ${ }^{3}$ \\ ${ }^{1,2,3}$ Program Studi Teknik Elektro, Fakultas Teknik Universitas Muhammadiyah Palembang \\ Palembang 30263, Indonesia \\ *Koresponden email: begawan_alfarezi@um-palembang.ac.id
}

Diterima: 12 Oktober 2021

Disetujui: 1 November 2021

\begin{abstract}
Solar cell tracking system is a system that uses the latest technology with combining solar tracking, the intensity of sunlight absorbed by solar cells can be optimized automatically. The purpose of this study is to make the Arduino-based solar monitoring system and load protection tool. The device is also equipped with an LDR sensor that detects the presence of sunlight, sends data from the LDR to Arduino and delivers signals to linear actuators. When the charge supplied by the battery exceeds the capacity of the battery, the INA219 sensor detects overload and a signal sent to Arduino asking for a relay to release the load. The results showed that tracking solar cell systems were successful in improving the efficiency of solar cells with an average power yield of 0.87 ampere of 12.62 watts from before without tracking the average obtained 0.62 ampere 8.83 atts. The performance of the protection system indicates that the load is cut off when the charging current exceeds the specified limit of 2.6 ampere.
\end{abstract}

Keywords: Battery, LDR, Modul INA219, tracking solar cell

\begin{abstract}
Abstrak
Sistem pelacakan sel surya merupakan sistem yang menggunakan teknologi terkini dengan menggabungkan pelacakan surya, intensitas sinar matahari yang diserap oleh sel surya dapat dioptimalkan secara automatic. Tujuan penelitian ini untuk membuat sistem pemantau surya berbasis Arduino dan alat proteksi beban lebih. Perangkat ini juga dilengkapi dengan sensor LDR yang mendeteksi keberadaan sinar matahari, mengirimkan data dari LDR ke Arduino dan memberikan sinyal ke aktuator linier. Ketika muatan yang dipasok oleh baterai melebihi kapasitas baterai, sensor INA219 mendeteksi kelebihan beban dan sinyal dikirim ke Arduino meminta relai untuk melepaskan beban. Hasil penelitian menunjukkan bahwa pelacakan sistem sel surya berhasil dalam meningkatkan efisiensi sel surya dengan hasil daya rata-rata yang di peroleh 0,87 Ampere 12,62 Watt dari sebelumnya tanpa tracking rata-rata yang diperoleh 0,62 Ampere 8,83 Watt. Kinerja sistem proteksi menunjukkan bahwa beban terputus ketika arus pengisian melebihi batas yang ditentukan yaitu 2,6 Ampere.
\end{abstract}

Kata Kunci: Baterai, LDR, modul INA219, pelacakan sel surya

\section{Pendahuluan}

Listrik merupakan salah satu kebutuhan yang sangat penting [1]. Kebutuhan energi saat ini merupakan produk esensial untuk mendukung aktivitas manusia, karena hampir semua kegiatan menggunakan listrik [2]. Oleh karena itu, pentingnya menyediakan sumber daya alternatif untuk mendapatkan daya [3]. Salah satu cara dalam penyediaan sumber daya alternatif adalah dengan pemanfaatan sinar matahari sebagai sumber energi [4].

Matahari merupakan salah satu dari beberapa sumber energi yang tidak terbatas, dan matahari merupakan salah satu jenis sumber energi terbarukan [5]. Di Indonesia, penggunaan sinar matahari menjadi sumber energi cenderung masih kurang dimanfaatkan secara optimal. Bila ditinjau, Indonesia terletak pada garis khatulistiwa dimana potensi dan pemanfaatan sinar matahari sebagai sumber energi sangat tinggi [6]. Menurut ref. [7], energi matahari dapat dikonversi dan manfaatkan menjadi energi listrik, misalnya penggunaan panel surya.

Panel surya merupakan alat yang digunakan untuk mengubah cahaya matahari menjadi tenaga listrik [8]. Solar sel dipasang secara permanen dengan sudut elevasi tetap atau biasa disebut sel surya statis [9].Namun demikian, teknik instalasi panel surya seperti ini memiliki kekurangan yaitu ketika matahari menjauh dari panel surya maka energi yang dihasilkan oleh panel juga akan berkurang [10]. Sel surya menghasilkan daya maksimum ketika matahari bersinar tegak lurus satu sama lain [11]. Panel surya 
mengubah sinar matahari menjadi listrik dirancang dengan sistem pelacakan yang dikendalikan melalui mikrokontroler Arduino [12].

Solar cell tracking merupakan sistem yang digunakan untuk melacak pergerakan matahari yang diterapkan pada panel surya dan bertujuan untuk memaksimalkan energi yang dihasilkan oleh sel surya [13]. Perancang sistem harus memperhatikan sudut kemiringan sel surya relatif terhadap sinar matahari yang datang sehingga intensitas penyerapan sinar matahari dapat memaksimalkan daya dihasilkan panel surya [14]. Panel surya digerakkan oleh motor putar atau aktuator linier dan uji sistem untuk memastikan posisi optimal panel surya relatif terhadap posisi matahari di langit [15].

\section{Metode Penelitian}

Penelitian rancang bangun solar cell tracking system dan proteksi overload berbasis Arduino, dimulai dengan menentukan konsep, perancangan subsistem, evaluasi dan simulasi keseluruhan sistem perancangan. Pada tahap selanjutnya dilakukan pengujian alat, pengambilan hasil data pengukuran dan analisis. Diagram alir perancangan penelitian dapat dilihat pada Gambar 1.

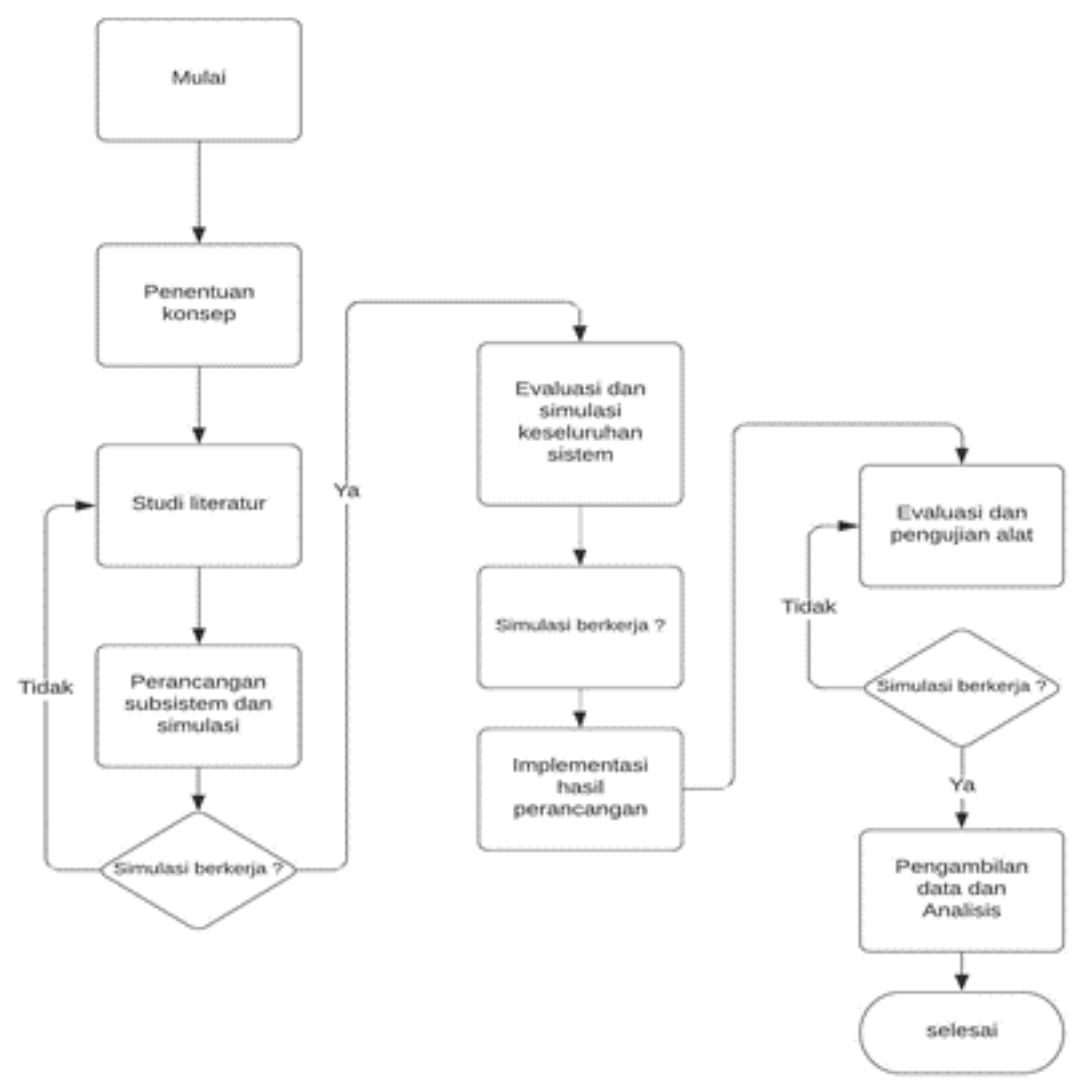

Gambar 1. Diagram alur penelitian

\section{Perancangan sistem}

Langkah pertama dalam pelacakan yaitu menempatkan matahari pada posisi yang diinginkan tegak lurus terhadap panel surya. Modul sensor LDR terlebih dahulu mendeteksi posisi matahari, kemudian modul memberi sinyal kepada Arduino untuk mengolah data dari modul LDR. 


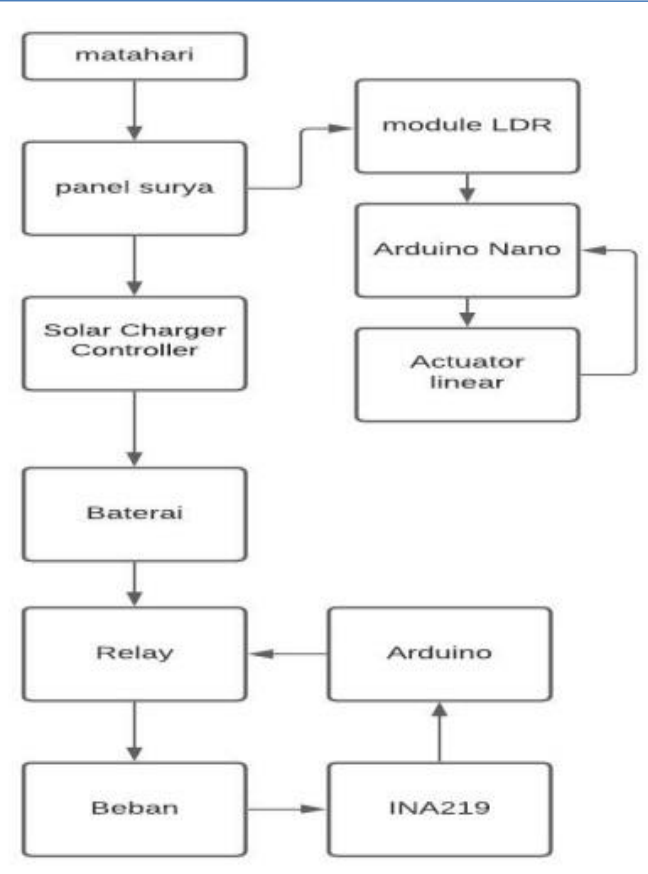

Gambar 2. Diagram prinsip kerja sistem

\section{Desain implementasi alat}

Setelah perakitan semua komponen yang digunakan untuk tracking sel surya dan melindunginya dari beban berlebih, peneliti mendesain alat yang bekerja paling baik dengan desain seperti yang terlihar pada Gambar 3.

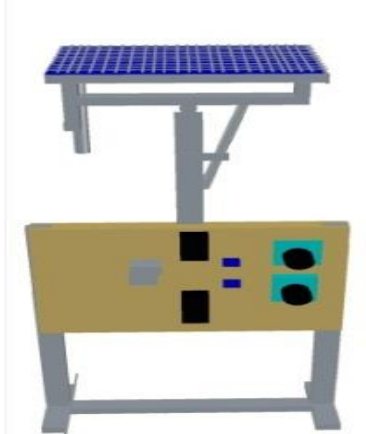

(a)

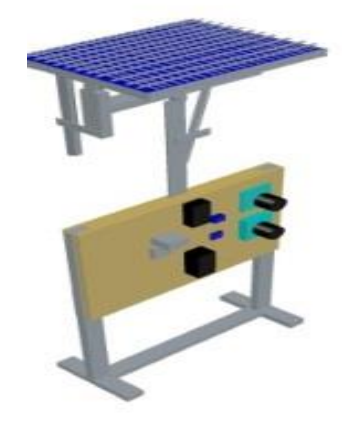

(b)

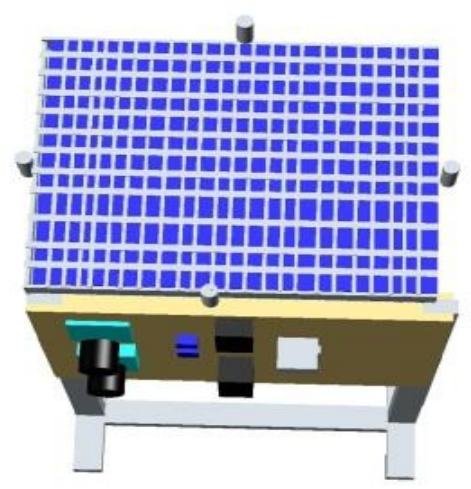

(c)

Gambar 3. Desain alat tracking system solar cell: (a) Tampak depan (b) Tampak samping (c) Tampak atas Sumber: Rancangan penelitian

Berdasarkan Gambar 3 (a), desain bagian depan sistem proteksi dan monitoring overload berbasis solar Arduino, ukuran pad yang digunakan adalah $50 \mathrm{~cm}$ x $50 \mathrm{~cm}$ x $150 \mathrm{~cm}$. Penyangga digunakan untuk 
memasang kaki besi dan panel surya serta braket besi. Penempatan mikrokontroler dan perangkat baterai dirancang seperti dijelaskan di atas untuk penempatan yang mudah. Gambar 3 (b) menunjukkan tampilan samping dari desain. Bagian ini menunjukkan aktuator linier yang menggerakkan sel surya dari timur ke barat, dari selatan ke utara. Gambar 3 (c) menunjukkan bahwa desain modul sensor LDR penting karena menentukan pergerakan panel surya sehingga tegak lurus terhadap matahari.

\section{Hasil dan Pembahasan}

Hasil penelitian dari kegiatan ini telah berhasil menciptakan suatu alat yang berfungsi sebagai sistem proteksi pada instalasi fotovoltaik dalam rangka meningkatkan efisiensi operasi sel surya dan memperpanjang umur sel fotovoltaik.

\section{Pengujian Sensor LDR (Light Dependent Resistor)}

Pengujian sensor LDR dilakukan untuk mengetahui kinerja dari sensor LDR saat menangkap intensitas cahaya matahari. Data ini digunakan oleh Arduino untuk awalnya mengarahkan NO (normally open) ke NC (normally close) relay. Dalam keadaan ini, aktuator bergerak secara linier sesuai dengan intensitas cahaya, bisa mendapatkan sinar matahari. Sensor ditempatkan di keempat sisi, yaitu atas, bawah, kiri, dan kanan.

\section{Pengujian actuator linear}

Pengujian actuator linear ini dilakukan untuk mengetahui kinerja dari actuator linear dalam menggerakkan panel surya, sehingga panel surya tersebut pada posisi yang tepat pada cahaya matahari. Ada dua actuator linier untuk diuji, di tengah dan bergerak ke kiri dan kanan, dan satu di atas dan bergerak ke atas dan ke bawah, seperti yang terlihat pada berikut ini :

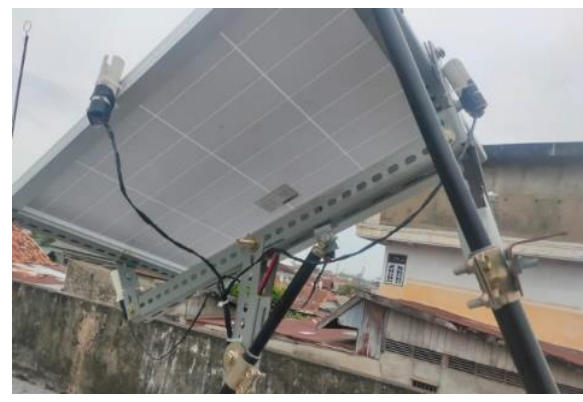

(a)

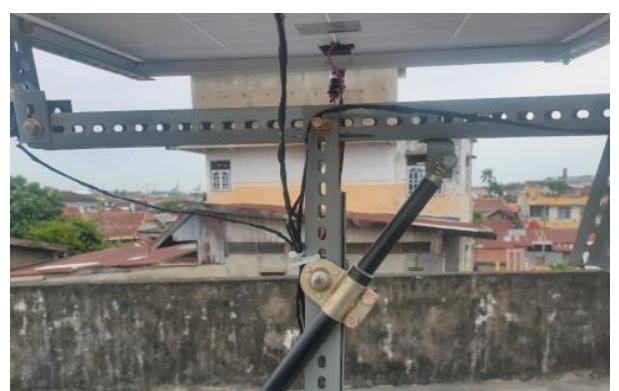

(b)

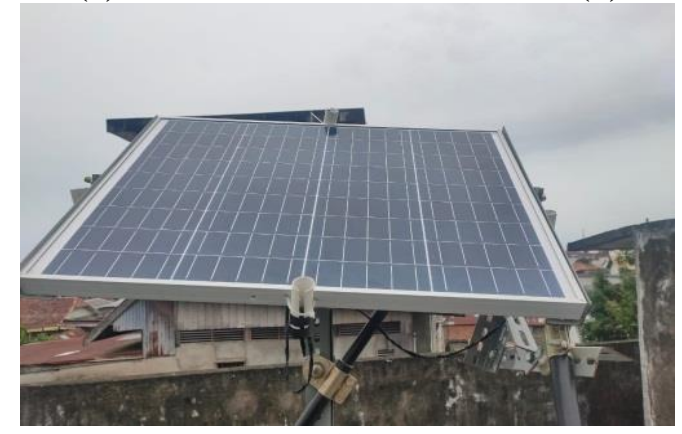

(c)

Gambar 4. actuator linear (a) kiri (b) tengah (c) kanan Sumber: Hasil penelitian

Berdasarkan Gambar 4 menjelaskan posisi actuator yang berubah secara adaptif terhadap sinar matahari yang terjadi pada saat pengukuran. Pada Gambar 4 (a) actuator linear tengah pada saat di sisi kiri 4 (b) actuator linear tengah pada saat di sisi tengah dan 4 (c) actuator linear tengah pada saat di sisi kanan. 


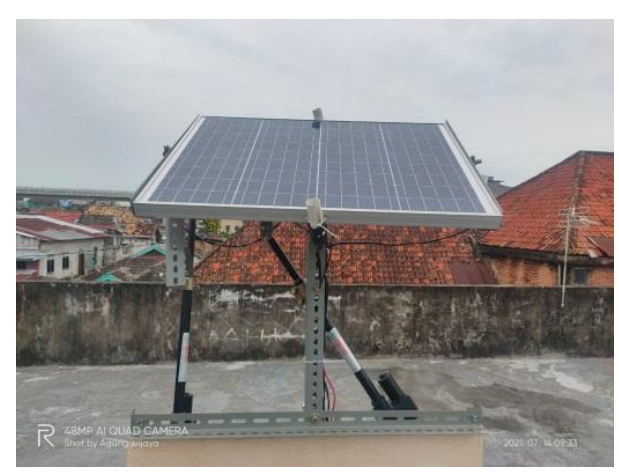

(a)

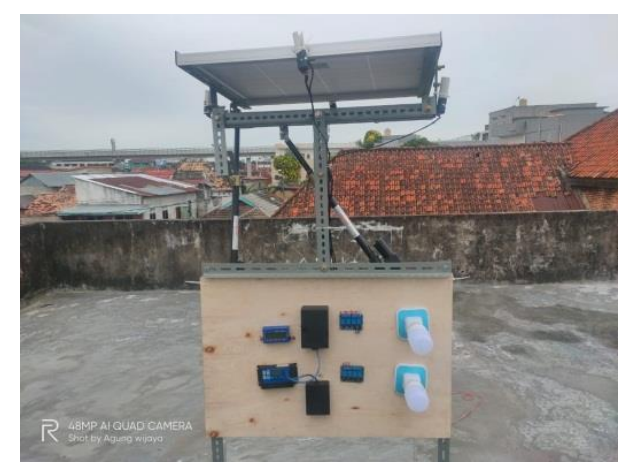

(b)

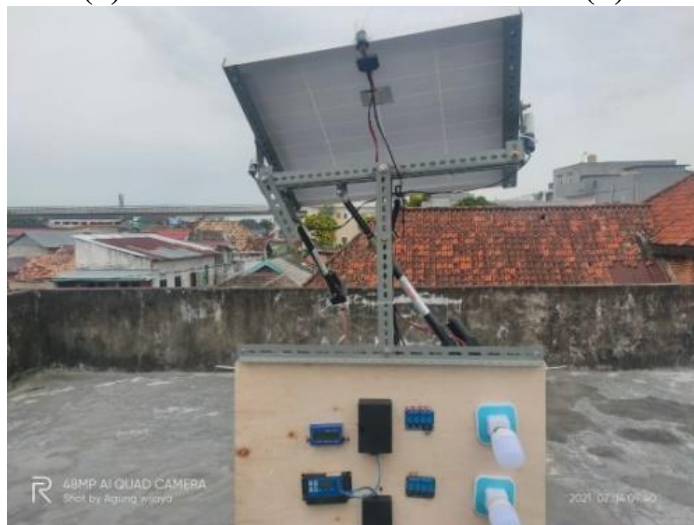

(c)

Gambar 5. Actuator linear (a) atas (b) tengah (c) bawah

Berdasarkan Gambar 5 (a), actuator linear atas pada saat di sisi atas (b) actuator linear atas pada saat di sisi tengah (c) actuator linear atas pada saat di sisi bawah.

\section{Pengujian Solar cell Tracking System}

Tes ini dilakukan untuk melihat apakah sel surya menghadap matahari. Untuk mengujinya, sistem pelacak surya ditempatkan di atap lantai tiga. Pengujian berlangsung mulai pukul 08:00 WIB hingga 17:00 WIB. Waktu tersebut efektif dari kerja radiasi matahari. Selama 08:00- 09:30 WIB posisi panel surya di sisi timur, pada siang hari pukul 11.00-13:00 WIB posisi panel surya di tengah, pada sore hari 15:00-17:00 WIB, panel solar tracker berada di sisi barat.

\section{Pengujian Solar cell}

Pada tahap ini dilakukan pengukuran selama 1 seminggu untuk mendapatkan pola antara tegangan, arus, dan daya yang dihasilkan pada tiap jam dalam 1 hari. Disamping itu, pada pengujian ini disajikan perbandingan antara tegangan, arus, dan daya pada saat tanpa penggunaan tracking solar cell dibandingkan dengan menggunakan tracking solar cell.

Tabel 2. Hasil rata-rata pengujian tracking solar cell selama 1 minggu

\begin{tabular}{ccccc}
\hline No & Jam & $\begin{array}{c}\text { Tegangan } \\
\text { (volt) }\end{array}$ & $\begin{array}{c}\text { Arus } \\
\text { (ampare) }\end{array}$ & $\begin{array}{c}\text { Daya } \\
\text { (watt) }\end{array}$ \\
\hline 1. & 8 & 15,41 & 0,45 & 6,40 \\
2. & 9 & 16,58 & 0,78 & 9,30 \\
3. & 10 & 17,35 & 0,85 & 11,24 \\
4. & 11 & 19,17 & 0,96 & 13,18 \\
5. & 12 & 20,63 & 1,24 & 14,40 \\
6. & 13 & 20,03 & 1,22 & 14,05 \\
7. & 14 & 19,73 & 0,98 & 15,44 \\
8. & 15 & 19,27 & 0,84 & 16,53 \\
9. & 16 & 19,01 & 0,72 & 15,07 \\
10. & 17 & 17,34 & 0,62 & 10,60 \\
\hline Rata-rata & \multicolumn{5}{c}{$0,87,45$} & 12,62 \\
\hline \multicolumn{5}{c}{ Sumber: Hasil penelitian }
\end{tabular}


Berdasarkan Tabel 2 terlihat bahwa nilai tegangan dan arus maksimum pada pukul 12:00 WIB adalah 20,63 volt dan 1,24 amp. Nilai tegangan dan arus minimum yang dihasilkan dari pengujian ini adalah 15,41 volt dan $0,45 \mathrm{amp}$, dengan tegangan rangkaian terbuka dan arus hubung singkat, namun hasil pengujian ini diperoleh pada pukul 08.00 WIB.

Tabel 3. Hasil rata-rata pengujian tanpa tracking solar cell selama 1 minggu

\begin{tabular}{ccccc}
\hline No. & Jam & $\begin{array}{c}\text { Tegangan } \\
\text { (volt) }\end{array}$ & Arus (ampere) & Daya (watt) \\
\hline 1. & 8 & 13,16 & 0,44 & 5,98 \\
2. & 9 & 15,33 & 0,53 & 9,07 \\
3. & 10 & 17,62 & 0,62 & 9,85 \\
4. & 11 & 18,91 & 0,74 & 10,1 \\
5. & 12 & 20,29 & 0,86 & 12,55 \\
6. & 13 & 19,62 & 0,82 & 11,42 \\
7. & 14 & 19,62 & 0,81 & 10,67 \\
8. & 15 & 19,56 & 0,63 & 7,91 \\
9. & 16 & 18,94 & 0,48 & 5,95 \\
10. & 17 & 16,31 & 0,32 & 4,83 \\
\hline \multicolumn{5}{r}{ Rata-rata } \\
\hline \multicolumn{5}{c}{ Sumber: Hasil penelitian }
\end{tabular}

Dapat dilihat dari Tabel 3 bahwa nilai tegangan dan arus maksimum adalah 12:00 WIB, dan tegangan rangkaian terbuka dan arus hubung singkat masing-masing adalah 20,29 volt dan 0,86 amp. Nilai tegangan dan arus minimum yang dihasilkan dari pengujian ini adalah tegangan rangkaian terbuka dan arus hubung singkat sebesar 13,16 volt dan 0,44 amp, namun hasil pengujian ini diperoleh pada pukul $08.00 \mathrm{WIB}$.

\section{Daya (watt)}

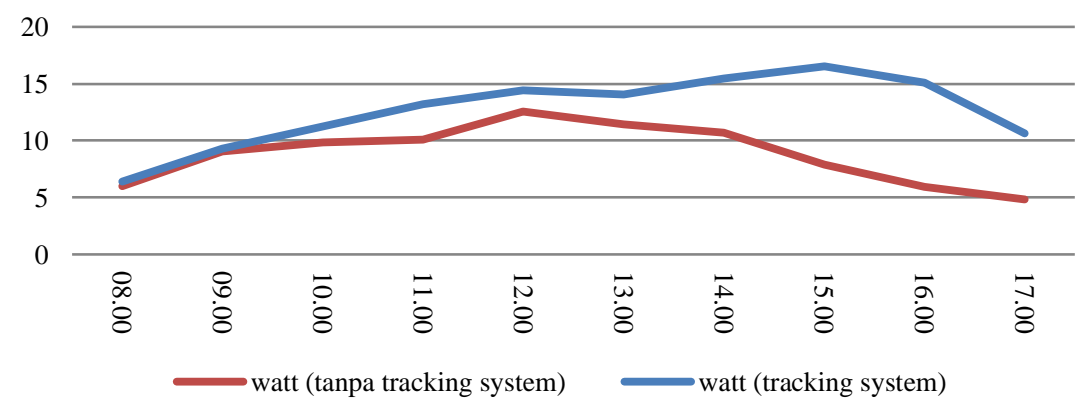

Gambar 6. Grafik perbandingan daya

Sumber: Hasil penelitian

Arus (Ampere)

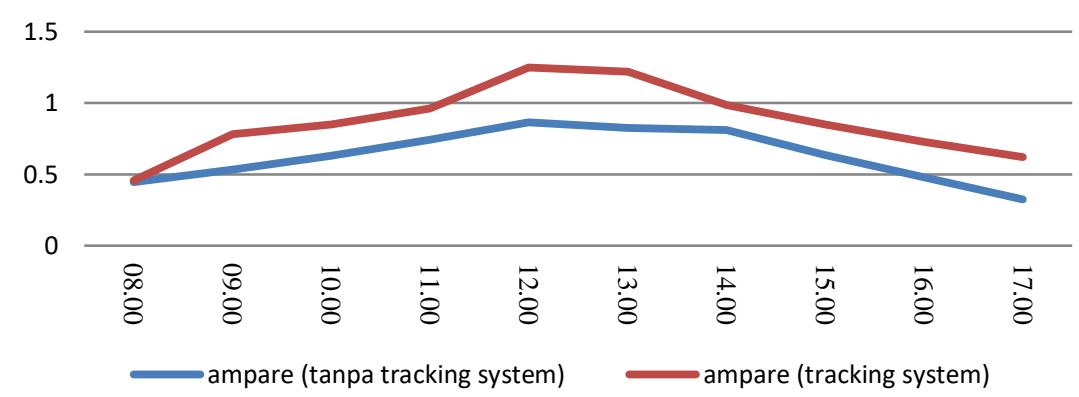

Gambar 7. Grafik perbandingan arus

Sumber: Hasil penelitian 
Tegangan (Volt)

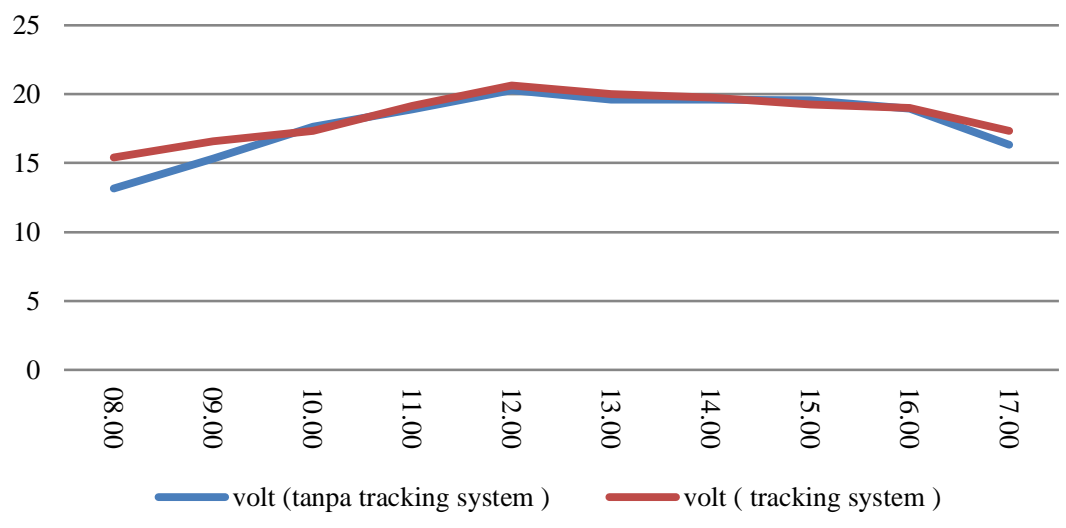

Gambar 8. Grafik perbandingan tegangan Sumber: Hasil penelitian

Dari Gambar 6 menunjukkan bahwa dengan penggunaan tracking solar cell memberikan efek peningkatan daya yang dihasilkan yang cukup signifikan yaitu $51.83 \%$ dari daya awal. Disamping itu, pada Gambar 7 juga menunjukkan bahwa arus yang dihasilkan dengan penggunaan tracking solar cell dapat meningkatkan arus yang cukup signifikan yaitu $40.73 \%$, dimana tegangan yang dihasilkan tidak terlalu berbeda jauh.

\section{Pengujian Sistem Proteksi Solar cell}

Sistem proteksi sel surya bertujuan untuk memperpanjang masa pakai baterai dengan mencegah kerusakan pada sistem pelacakan panel surya dan memutuskan sisi beban agar tidak melebihi kapasitas baterai. Pada pengujian ini menggunakan beban lampu DC 2 x 15 watt. Arduino mengatur arus minimum yang dapat dibaca oleh INA219 sehingga disesuaikan ketika arus total lebih dari 2.6 Ampere. Sensor INA219 mendeteksi beban berlebih maka sensor INA219 akan mengirimkan data ke Arduino. Kemudian Arduino memerintahkan relay dari normally open menjadi normally close. Pastikan sisi beban terputus dalam kondisi ini. Kemudian saat tegangan baterai terbaca maka sensor INA219 menampilkan arus DC sebesar 12 volt, sensor INA219 mengirimkan data ke Arduino, Arduino terlebih dahulu menggerakkan relay dari NO ke NC. Proses ini bertujuan untuk memperpanjang umur baterai. Menggunakan lebih dari kapasitas baterai dapat mempersingkat masa pakai baterai. Baterai mengonsumsi lebih banyak arus dan merusak sel baterai.

\section{Kesimpulan}

Penggunaan tracking solar cell dapat memberikan efek peningkatan daya yang dihasilkan yang cukup signifikan yaitu 51,83\% dari daya awal. Disamping itu juga menunjukkan bahwa dengan penggunaan tracking solar cell dapat meningkatkan arus yang cukup signifikan yaitu 40,73\%, dimana tegangan yang dihasilkan tidak terlalu berbeda jauh. Kinerja sistem proteksi menunjukkan bahwa beban terputus ketika arus pengisian melebihi batas yang ditentukan yaitu 2,6 Ampere.

\section{Referensi}

[1] S. Nurharsanto dan A. Prayitno, "Sun tracking otomatis untuk pembangkit listrik tenaga surya (PLTS)," Jom FTEKNIK, vol. 4 (2), hal. 1-6, 2017.

[2] P. Harahap, "Pengaruh temperatur permukaan panel surya terhadap daya yang dihasilkan dari berbagai jenis sel surya," RELE (Rekayasa Elektr. dan Energi) J. Tek. Elektro, vol. 2 (2), hal. 73 80, 2020, doi: 10.30596/rele.v2i2.4420.

[3] R. W. Tricahyono dan N. Kholis, "Sistem monitoring intensitas cahaya dan daya pada dual axis solar tracking system berbasis IoT," J. Teknik Elektro, vol. 7 (3), hal. 233-238, 2018.

[4] W. Yandi, Syafii, dan A. B. Pulungan, "Tracker tiga posisi panel surya untuk peningkatan konversi energi dengan catu daya rendah," vol. 6 (3), 2017, doi: 10.20449/jnte.v6i3.468.

[5] H. S. Utomo, T. Hardianto, dan B. S. Kaloko, "Optimalisasi daya dan energi listrik pada panel surya polikristal dengan teknologi scanning reflektor," Berk. Sainstek, vol. 5 (1), p. 45-49, 2017, doi: 10.19184/bst.v5i1.5375.

[6] H. Suryawinata, D. Purwanti, dan S. Sunardiyo, "Sistem Monitoring Pada Panel Surya Menggunakan Data Logger Berbasis Atmega 328 Dan Real Time Clock DS1307," J. Tek. Elektro, 
vol. 9 (1), pp. 30-36, 2017, doi: 10.15294/jte.v9i1.10709.

[7] M. Asri dan Serwin, "Rancang bangun solar tracking system untuk optimasi output daya pada panel surya," J. Inf. Sains dan Teknol., vol. 4 (1), 2019.

[8] M. Irfan, I. Pakaya, and A. Faruq, "Penentuan posisi sudut matahari menggunakan anfis dalam aplikasi tracker panel surya," J. Nas. Tek. Elektro, vol. 8 (3), 2019, doi: 10.25077/jnte.v8n3.671.2019.

[9] F. Hidayanti, F. Rahmah, and M. Ikrimah, "Dual-axis solar tracking system efficiency for hydroponics pump," Int. J. Emerg. Trends Eng. Res., vol. 8 (6), pp. 2631-2634, 2020, doi: 10.30534/ijeter/2020/67862020.

[10] R. Khotama, D. B. Santoso, and A. Stefanie, "Perancangan sistem optimasi smart solar electrical pada pembangkit listrik tenaga surya (PLTS) dengan metode tracking dual axis technology," $J$. Ecotipe (Electronic, Control. Telecommun. Information, Power Eng.), vol. 7 (2), hal. 78-84, 2020, doi: 10.33019/jurnalecotipe.v7i2.1887.

[11] Wendryanto, G. Widayana, dan W. Sutaya, "Pengembangan penggerak solar panel dua sumbu untuk meningkatkan daya pada solar panel tipe polikristal," J. Pendidik. Tek. Mesin Undiksha, vol. 5 (3), hal. 62-70, 2019, doi: 10.23887/jjtm.v5i3.20293.

[12] K. W. Fauzi, T. Arfianto, and N. Taryana, "Perancangan dan realisasi solar tracking system untuk peningkatan efisiensi panel surya menggunakan arduino uno," TELKA - Telekomun. Elektron. Komputasi dan Kontrol, vol. 4, no. 1, pp. 63-74, 2018, doi: 10.15575/telka.v4n1.63-74.

[13] R. J. D. Lesmana dan A. I. Agung, "Rancang bangun solar cell tracking system dan proteksi beban lebih berbasis arduino," J. Tek. Elektro, vol. 8 (1), hal. 229-237, 2019.

[14] A. D. Putra, A. B. Pulungan, dan I. Yelfianhar, "Optimalisasi penyerapan energi matahari menggunakan sistem solar tracking dua sumbu," JTEV (Jurnal Tek. Elektro dan Vokasional), vol. 6 (2), p. 187, 2020, doi: 10.24036/jtev.v6i2.108552.

[15] A. U. Azmy, Sumardi, dan M. A. Riyadi, "Sistem tracking panel surya untuk pengoptimalan daya menggunakan metode kontrol self-tuning Pid dengan Jst jenis perceptron," Transmisi, vol. 17 (1), hal. 35-41, 2015, doi: 10.12777/transmisi.17.1.35-41. 